\title{
Designing verbal messages and visual media for the tourism destination of Curug Putri
}

\author{
S. Nurbani, J. Haiba, Y.A. Barlian \& A.R. Ramadhan \\ Telkom University, Bandung, Indonesia
}

\begin{abstract}
Curug Putri Campground is a natural tourist destination in Palutungan, West Java that has a uniquely shaped waterfall resembling a princess and a mythical story believed by the surrounding community. That makes this location full of potential for tourism yet due to a lack of promotion and the emergence of competitors in the area, the number of visitors coming to this place has been decreasing. The purpose of this research is to design a main message and visual media to promote Curug Putri Campground. The research method used is qualitative. The main verbal message is designed through the analysis of creative strategies of word meaning and visual media strategies using creative strategy theory and visual media. By designing a verbal message and visual media appropriately, it is the hope that this promotion can be delivered effectively, leading to an increase in visitors to Curug Putri which would help to improve the local economy.
\end{abstract}

Keywords: verbal message, visual media, word meaning, Promotion, Curug Putri, creative strategy

\section{INTRODUCTION}

Indonesia has many tourist destinations. If the government is able to take advantage of the existing potential and is able to work with local communities, they could work together on development that would help improve the country's economy. Tourism has the potential to overcome welfare problems if developed professionally.

Palutungan Curug Putri Campground has made various efforts such as completing and maintaining the beauty of the area in an effort to compete with other tourism destinations. Curug Putri has many advantages over other locations such as having a large piece of land, complete facilities, easy access, and a unique waterfall which is believed to be a miracle. However, due to the lack of promotion, Palutungan Curug Putri Campground has experienced a decline and fluctuation in the number of visitors since 2014.

Based on the results of interviews with the director of CV. Putri Mustika Tourism, promotions have been carried out in the form of word of mouth and direct marketing promotions by visiting public and private agencies as well as schools. Direct marketing can build relationships between buyers and sellers more effectively (Kotler \&Armstrong 2008). Promotions are felt to be less effective, so creative strategies are needed to achieve the desired results. Therefore, based on these phenomena and problems, Palutungan Curug Putri Campground needs to be promoted by designing appropriate message strategies and visual media so as to have the desired effect on the target audience.

\subsection{Word meaning}

Words take on different meaning depending on how they are used in everyday life. According to Abdul Chaer (1994), a lexical meaning can also be called a true meaning. For example, "water" means a type of liquid that is used every day. A grammatical meaning is the result of grammar 
or grammatical processes. Contextual meaning is the meaning of a word or lexicon that appears based on a particular context. Referential is a meaning that has a reference to it in the real world. Non-referential meaning is the opposite of referential meaning. Denotative meaning is the original meaning, the original, or even the actual meaning that a word has that does not have any other hidden meaning. Connotative meaning is another meaning that uses the word. Conceptual meaning is the meaning possessed by a word that is independent of any context or association. Associative meaning is the meaning of words that arise because of the relationship of these words with other things outside the language. Word meaning describes several words as words that have a common or similar meaning. Term meaning is the opposite of the meaning of the word. Idiom meaning is the meaning of a word contained in a certain group of words, where the meaning formed is different from the original meaning of the word. Proverb meaning is similar to an idiom meaning in that it arises due to the formation of certain phrases or collections of words.

\subsection{Advertising}

Advertising is a complex form of communication that sets goals and uses strategies to influence the thoughts, feelings, and actions of consumers (Moriarty et al. 2011). Advertising or an "ad" is the overall broad communication about a product, service, or goods paid by a particular sponsor (Morissan 2010).

\subsection{Creative strategy}

According to Lee and Johnson (2011), the attractiveness of advertising is the approach taken in advertising to attract the attention of the target audience to influence their feelings toward the product/service. The attractiveness of advertising is Informational/Rational (Aggressive Sales); this attraction focuses on the practical and functional needs of consumers for products or services. Emotional Attractiveness (Persuasive Sales) is attraction that uses emotional messages and is designed around images expected to touch the heart. Combination Attraction combines informational/rational and emotional appeal.

AISAS is an advertising design model of The Dentsu Way that is effective for the target audience with behavior changes happening now due to the development of the internet. AISAS stands for Attention, Interest, Search, Action, and Share (Sugiyama \&Andre 2011).

\subsection{Media}

The word "media" has the mediator of the message from the sender to the recipient, or the intermediary introducing the message or in Arabic known as waasai (Arsyad 2002). According to Belch (in Morissan 2010), the media is an intermediary who sends messages including television, newspapers, radio, and other supporting media. From the above definition, the media is an intermediary or messenger including broadcast media, print media, digital media, outdoor media, and other supporting media.

\subsection{Visual communication design}

Visual Communication Design can be defined as an amalgamation of applications and skills from design elements such as layout, color, typography, visuals, and communication for business and industrial needs. Visual communication design is an art to convey a message of information using the form as the language that is conveyed through media in the form of design (Anggraini and Nathalia 2018). 


\section{RESEARCH METHODS}

In conducting this research, the authors used qualitative research methods because most of it refers to the phenomena that occur in society. Strengthened by the explanation from Moleong, qualitative research is research that is intended for the phenomenon of the behavior, perception, motivation, and action holistically by means of description (Moleong 2005). Data collection uses triangulation of data, namely observation, interviews, and literature study. Observation is a method of looking directly into the field (Sugiyono 2013). The data was obtained based on direct observation of the tourist destinations of Bumi Perkut and Palutungan Curug Putri on July 10, 2019 and August 18, 2019.

\section{RESULT AND DISCUSSION}

\subsection{Concept of verbal message}

Verbal messages, commonly referred to as copywriting, or in this case the tagline, are obtained from a creative strategy by combining Unique Selling Proposition (USP), Benefit, and Insight from the target audience. From these three elements, the proposition can be taken as the main message that Curug Putri has complete facilities and unique waterfall shapes, reflecting the shape of a mythical princess who was the daughter of heaven and water. This waterfall is believed to be efficacious and able to provide new and unique experiences for visitors. From this angle, a tagline is taken from the key phrase Beyond the Magical Curug.

The types of meanings used in the design of verbal messages in the form of taglines and headlines are contextual and associative. In this case, the word "beyond" contains contextual meaning that will depend on what is discussed, in this case referring to the facilities in Curug Putri as the selling power of this tourist area which is generated from the USP of this Putri waterfall tour. The word "The magical" is included in the associative meaning - in this case, the myth of a heavenly princess and water believed to be efficacious. The word "Curug" is included in the conceptual meaning because the concept of Curug is a waterfall.

Therefore, with the formation of the contextual, association, and conceptual meanings, verbal messages, in this case, a tagline, can be conveyed clearly to the target audience and can be received clearly without dual or multiple meanings. Henceforth, this verbal language will be strengthened or the visual language will be strengthened so that it the minds of consumers become clearer over the meaning or message conveyed by advertisers (Nurbani and Nanda 2019).

\subsection{Visual media}

\subsubsection{Target audience}

To obtain strategies and the right media in accordance with the target audience, the activities of the target audience will be deepened to discover how effective the media is in promoting the Curug Putri. The results from the mood board above show that the target audience likes things related to nature and hanging out with friends, traveling, culinary, trying new and unique things, following trends, and liking tranquility.

\subsubsection{Typography}

In the design of the promotion of Curug Putri Campground, the Sans Serif typeface is used to make it more friendly and modern. It uses Balbeer fonts for headlines and letter affirmations and use Gotham fonts for body copy.

\subsubsection{Color}

The color used is an earth tone. A grayish white color is from the small rocks of the mountains, dark green is the color of the leaves, the maroon color is the brownish color of the earth, and the 
Table: AISAS

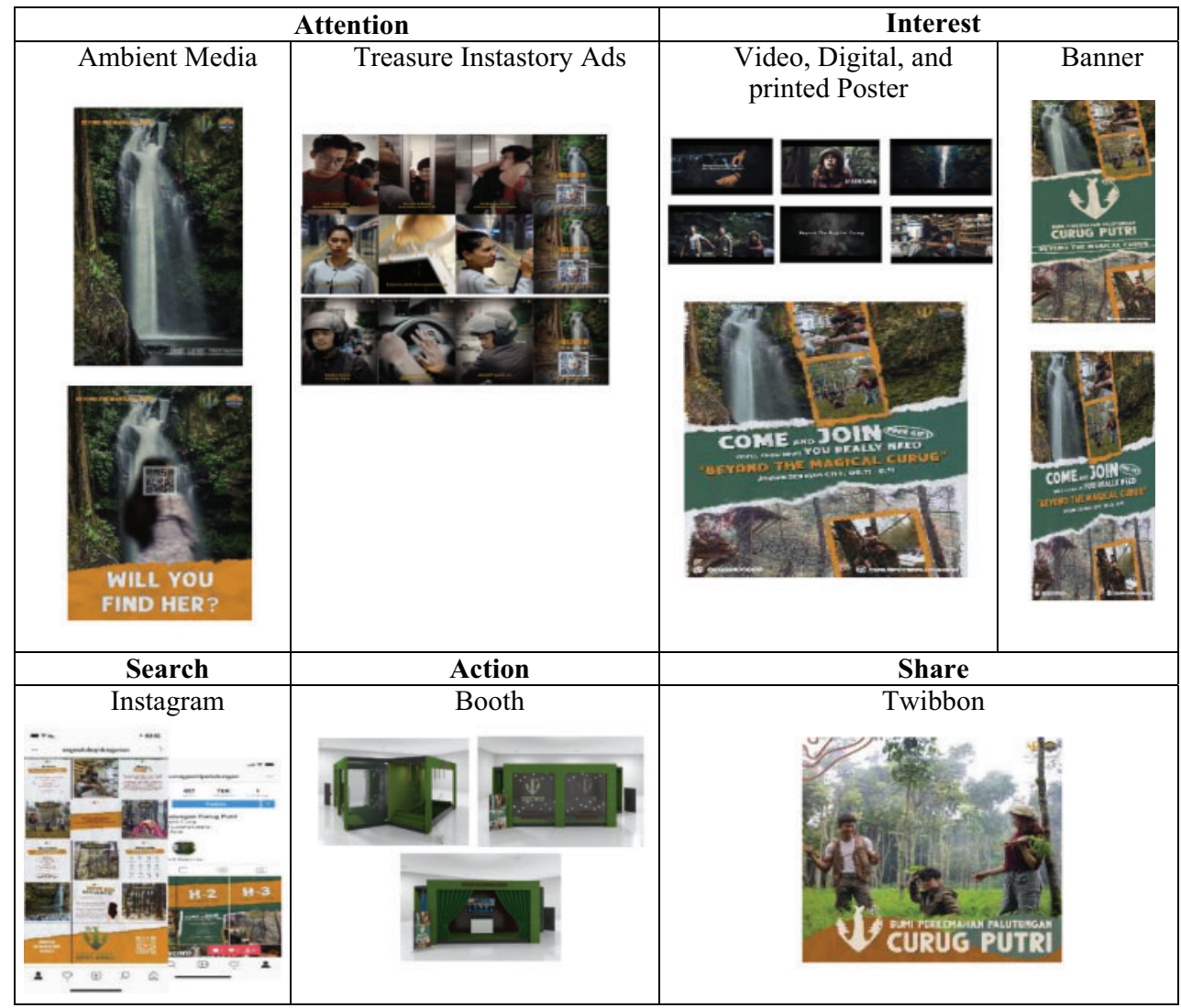

Source: Authors' Documentation

orange-yellow color matches the sun. So, it is expected that the colors bring the impression of comfort and strength.

\subsubsection{Design results \\ Attention}

Ambient media is able to give a deep massage to the target audience by providing a direct experience so that the target audience can immediately feel the truth. The choice of location of the elevator at the shopping center is the result of a survey of places often passed on by the target audience.

\section{Interest}

At the stage of interest, it uses information communication and persuasion strategies that are packaged with a video. Videos will be placed in the media using YouTube and Instagram. For YouTube videos containing Instagram address information the target audience can be directed to Instagram. Through the Instagram swipe up features, digital posters on Instagram ads that containing booth information can directing the information to Instagram feed. The banner that will be installed at the mall is also installed on the side of the road which contains information about the booth.

\section{Search}

The search stage uses information communication and persuasion strategies. Instagram content introduces the background, myths, facilities, and figures of workers who are tired of their activities 
and become a guide and complete information about the existence of brand activation. By using information communication strategies and brand activation persuasion in the form of booth experience, where visitors can feel and get information about Curug Putri, visitors have the opportunity to get free merchandise. The booth experience is made with three sides like a pop-up.

Share

The entry requirement to the booth is that visitors share their experiences on social media with the \#BuperBuangBaper hashtag. Twibbon will be used when the target audience shares their activities at the booth and when visiting the Palutungan Curug Putri Campground.

\section{CONCLUSION}

The main advertising message is very important in determining what will be communicated to the target audience, so that the target audience can understand and accept the message well and the decision to purchase or use the product can be highly considered. Aside from a good message, visual media strategies also determine the message to be communicated effectively. Both of these are obtained from determining the right creative strategy so that promotion can be done effectively. This will affect the main goal of increasing the number of visitors to come to the Curug Putri Campground so that the region's economy can be lifted up and indirectly help solve the nation's problems related to poverty.

\section{ACKNOWLEDGMENT}

Thank you to all parties who provided the data and thank you to the previous researchers. Thank you to PPM Telkom University for providing internal funding for this research.

\section{REFERENCES}

Arsyad, Azhar. 2002. Media Pembelajaran, edisi 1. Jakarta: PT. Raja Grafindo Persada.

Belch, George E. and Michal, A. 2009. Advertising and Promotion: An Integrated Marketing Communication Perspective, 8th edition. New York: Pearson Education.

Chaer. 1994. Linguistik Umum. Jakarta: Rineka Cipta

Kotler, Philip and Armstrong, Garry. 2008. Prinsip-prinsip Pemasaran, Jilid 1, Erlangga, Jakarta

Lia Anggraini, S. and Nathalia, Kirana. 2018. Desain Komunikasi Visual; Dasar-dasar Panduan Untuk Pemula. Bandung: Penerbit Nuasa.

Moleong, Lexy J. 2005. Metodologi penelitian kualitatif, Bandung: Remaja Rosdakarya

Monle lee dan Carla Johnson. 2011. Prinsip-prinsip Pokok Periklanan dalam Persfektif Global. Kencana Prenada Media Group.

Moriarty, Sandra, Nancy Mitchell, Wells, William D. 2011. Advertising Edisi 8. Jakarta: Kencana Prenada Media Group.

Morissan. 2010. Periklanan komunikasi pemasaran terpadu, Jakarta: Penerbit Kencana

Nurbani, S. and Nanda Ayu R. Dewi. 2019. Designing Verbal Message And Visual Media Of Quick Chicken. 6th Bandung Creative Movement 2019, Bandung, Indonesia, October 2019. Telkom University, pp. 446-450.

Sugiyama, Kotaro and Andre, Tim. 2011. The Dentsu Way. New York: McGraw-Hill.

Sugiyono. 2013. Metode Penelitian Pendidikan Pendekatan Kuantitatif, Kualitatif, dan R\&D. Bandung: Alfabeta. 